Łukasz Jan Berezowski

\title{
HISTORIA TEUMACZEŃ SĄDOWYCH: OD NORYMBERGI DO HAGI (70 LAT DOŚWIADCZEŃ)
}

\author{
The history of court interpreting: \\ from Nuremberg to The Hague (70 years of experience)
}

\begin{abstract}
The main objective of the article is to set out the historical aspects of cooperation between interpreters and the judiciary in the contemporary era, which is inextricably linked with the most historical events of the $20^{\text {th }}$ century. In this regard, not negligible is the involvement of interpreters in the Nuremberg trials (1945-49) before the International Criminal Tribunal for the former Yugoslavia (1993) and Rwanda (1994) as well as, last but not least, in the foundation of the first permanent criminal tribunal in The Hague (International Court of Justice, ICJ). In conclusion, it is important to emphasize that the character of work as court interpreter, which is apparently corresponding to community interpreting, constitutes a separate category of translation studies given the criteria of high standards and professional ethics.
\end{abstract}

Key words: court interpreting, international judiciary, legal translation, Nuremberg trials, translation techniques

Słowa kluczowe: procesy norymberskie, przekład prawny, przekład sądowy, techniki tłumaczeniowe, sądownictwo międzynarodowe

„Tłumaczenie sądowe” to szczególna forma przekładu języka prawa, a precyzyjniej przekładu praktyki orzeczniczej stosowanej współcześnie w technolekcie prawnym. W polskiej tradycji językoznawczej u podstaw rozróżnienia zasadniczych pojęć leży dychotomiczny podział dokonany w 1941 r. przez Bronisława Wróblewskiego, a opisany w pracy wydanej pośmiertnie siedem lat później pt. Język prawny i prawniczy. Język prawny w tym rozumieniu to język ustawodawcy, którego używa się do tworzenia przepisów prawa, czyli język aktów normatywnych i przepisów ${ }^{1}$; język prawniczy zaś to język, którym posługują się prawnicy mający na co dzień

1 B. Wróblewski, Język prawny i prawniczy, Polska Akademia Umiejętności, Kraków 1948, s. 51-53. 
do czynienia z praktyką jurystyczną ${ }^{2}$. Język prawniczy jest więc swoistym metakodem w stosunku do języka prawnego, podczas gdy dystynkcja pomiędzy nimi przebiega w oparciu o kryterium podmiotowe. Dla przykładu: to, co polski kodeks karny definiuje jako „zabór mienia” jest w istocie kradzieżą, „termin zawity” - terminem nieprzekraczalnym, a „poręczenie majątkowe” to kaucja. Warto jednak odnotować, że wspomniany podział, choć nieopisany naukowo, funkcjonował de facto już od końca XVIII wieku, kiedy to w Zbiorze spraw sadowych z 1778 r., zwanym Kodeksem Andrzeja Zamoyskiego, rozróżniono język prawny i prawniczy (jako odpowiednio język doktryny i judykatury), jednak nie nazwano ich expressis verbis.

Kontynuując kwestie taksonomiczne, „tłumaczenie sądowe” uważane jest za szczególną odmianę tłumaczenia środowiskowego, które z kolei definiowane jest bardziej szczegółowo jako tłumaczenie bilateralne w sytuacji wielojęzyczności, gdy tłumacz nie tylko przekazuje treść wypowiedzi, ale także może $\mathrm{w}$ tę wypowiedź ingerowaćs. Ponadto tłumaczenie środowiskowe ma miejsce $\mathrm{w}$ dyplomacji, $\mathrm{w}$ turystyce, w mediach czy w negocjacjach biznesowych. Zatem instytucje wymiaru sprawiedliwości są jednym $\mathrm{z}$ wielu beneficjentów tłumaczenia środowiskowego. Wskazuje się przy tym na specyficzne i niesprzyjające warunki pracy tłumacza sądowego, do których należą: tłumaczenie długich fragmentów wypowiedzi praktycznie bez możliwości sporządzenia notatek, brak kabin do tłumaczenia symultanicznego na sali sądowej, zawiłość materii wykraczająca nierzadko poza rejestr języka standardowego (np. teksty z zakresu ekonomii i finansów, medycyny, nauk technicznych etc.). Ten ostatni problem jest odczuwalny nie tylko dla samego tlumacza, ale i dla uczestniczącego w procesie cudzoziemca, który z uwagi na rozmaite czynniki (wiek, stopień alfabetyzacji, wykształcenie bądź wykonywany zawód) często miewa kłopoty ze zrozumieniem zawiłych pojęć prawnych mimo wysokiego poziomu przekładu dostarczanego mu przez thumacza.

Zestawiając pojęcie przekładu sądowego z przekładem konferencyjnym, należy wyraźnie zaznaczyć, że o wiele istotniejsze dla świadka czy też oskarżonego pochodzącego z zagranicy jest to, aby inni uczestnicy postępowania sądowego go rozumieli oraz aby tłumacz należycie przełożył wygłaszane przezeń treści, aniżeli dla odbiorcy przekładu konferencyjnego, co ma swoje wytłumaczenie w twierdzeniu, że poza typową usługą tłumaczeniową mamy tu do czynienia ze współudziałem w kreowaniu decyzji o losie osoby tłumaczonej ${ }^{4}$.

2 Ibidem, s. 136-139.

3 J. Pieńkos, Podstawy juryslingwistyki. Język w prawie - Prawo w języku, Muza SA, Warszawa 1999, s. 132.

4 A. Biernacka, Tłumacz w rozprawie sądowej, Wydawnictwo Naukowe Instytutu Kulturologii i Lingwistyki Antropocentrycznej, Uniwersytet Warszawski, Warszawa 2014, s. 36. 
Przekład sądowy ma zatem służyć osobie sądzonej w takim sensie, że jest jednym ze sposobów realizacji jej prawa do uczciwego procesu, wynikającego wprost z Konwencji o ochronie praw człowieka i podstawowych wolności z 1950 r., a mającego swoje przełożenie na jurysdykcje narodowe. Wyraźny nacisk położony na znaczenie udziału tłumacza w rozprawie sądowej uosabia wymienione prawo osoby sądzonej do obrony i, wreszcie, podkreśla ogromną odpowiedzialność (zawodową i etyczną) tłu macza jako mediatora - pośrednika między językiem i kulturą kraju, w którym proces się toczy a językiem i kulturą osoby bądź grupy osób, będących uczestnikami postępowania.

Przejdźmy teraz do tematu przewodniego niniejszego tekstu, jakim jest historia przekładu sądowego. Przekład towarzyszy człowiekowi od początków istnienia ludzkości, a przynajmniej od czasu pojawienia się mowy ludzkiej. Język stanowi bowiem jeden z najsilniejszych nośników przekazu informacji. Zanim pojawiło się słowo mówione, ludzie musieli komunikować się za pomocą znaków, symboli i dźwięków, które stopniowo zaczęły pełnić rolę desygnatów konkretnych obiektów, uczuć lub zdarzeń. Zróżnicowanie językowe świata zmuszało nolens volens wybrane jednostki do wielojęzyczności. Podróżujący po świecie handlarze mogą być dziś uważani za protospecjalistów branży tłumaczeniowej. Ujmując rzecz $\mathrm{w}$ dużym uproszczeniu, to właśnie $\mathrm{z}$ ich nieformalnej praktyki interpretowania, wynikłej z potrzeb chwili w danym kontekście sytuacyjnym, ukonstytuowała się tak dobrze znana współcześnie sztuka tłumaczeniowa.

W literaturze przedmiotu próżno jednak szukać dobrze udokumentowanych odległych historycznie procesów z udziałem cudzoziemców, w które zaangażowani byli tłumacze. Szczątkowo wzmianki na ten temat odnajdujemy w egipskim piśmie hieroglificznym, w pracach Horacego i Cycerona, którzy odnotowali sądzenie najeźdźców w starożytnym Rzymie. Relację z dwóch procesów z udziałem obcokrajowca w nowożytnej Anglii (odpowiednio w 1682 i 1820 r.) odnajdujemy w pracy Jean Colin i Ruth Morris pt. Interpreters and the Legal Process ${ }^{5}$. Momentem przełomowym w historii tłumaczenia sądowego okazał się okres bezpośrednio po II wojnie światowej, „[...] kiedy rola tłumaczy w rozstrzyganiu o ludzkich losach nabrała przełomowego znaczenia w dziejach ich zawodu". Należy przywołać w tym kontekście przede wszystkim procesy norymberskie, odbywające się od 20 listopada 1945 do 13 kwietnia 1949 r., w trakcie których osądzono zbrodniarzy hitlerowskich (m.in. Hermanna Goeringa, Joachima von Ribbentropa czy Martina Bormanna). Wydarzenie to uważane jest dzisiaj nie tylko za kamień milowy w rozwoju przekładu sądowego i pierwszy udokumentowany proces tego typu, ale również punkt zwrotny w rozwoju zawodu tłumacza konferencyjnego.

${ }^{5}$ J. Colin, R. Morris, Interpreters and the Legal Process, Waterside Press, Winchester 1996.

${ }^{6}$ D. Kierzkowska, Ttumaczenia prawnicze, Wydawnictwo Translegis, Warszawa 2008, s. 66. 
Warto w tym miejscu nadmienić, że procesy norymberskie są najprecyzyjniej opisanymi, acz nie jedynymi historycznymi postępowaniami sądowymi, w których brali udział tłumacze. Niemalże równolegle do nich toczył się proces tokijski (od 29 kwietnia 1946 do 12 listopada 1948 r.) przed Międzynarodowym Trybunałem Wojskowym dla Dalekiego Wschodu.

Zawód tłumacza sądowego rozwijał się w XX w. równolegle do zawodu tłumacza konferencyjnego. Podczas procesów norymberskich „[...] po raz pierwszy użyto sprzętu elektronicznego, który umożliwiał komunikację oraz nagrywanie wersji oryginalnych oraz tłumaczeń wypowiedzi"7. Zarówno uczestnicy postępowania, jak i przedstawiciele prasy oraz publiczność mogli obserwować i śledzić wydarzenia dzięki słuchawkom. Należy zauważyć, że tłumacze zatrudnieni podczas procesu - przekładający wypowiedzi oskarżonych niejednokrotnie władających językami uży wanymi podczas rozpraw - mieli trudne zadanie nieulegania sugestiom oskarżonych dotyczącym prawidłowego tłumaczenia poszczególnych wypowiedzi, a co za tym idzie - zachowania bezstronności i neutralności.

W kontekście polskim istotnym wydarzeniem w rozwoju tłumaczenia sądowego i zarazem konferencyjnego był toczący się przed Najwyższym Trybunałem Narodowym w Poznaniu od 22 czerwca do 7 lipca 1946 r. proces Arthura Greisera, namiestnika Kraju Warty, a także kolejne: proces pierwszego komendanta obozu koncentracyjnego Auschwitz-Birkenau Rudolfa Hoessa przed Najwyższym Trybunałem Narodowym w Warszawie w dniach 11 marca -7 kwietnia 1947 r. oraz pierwszy proces oświęcimski przed Najwyższym Trybunałem Narodowym w Krakowie drugiego komendanta obozu koncentracyjnego Auschwitz-Birkenau Artura Liebehenschela i 39 innych członków załogi, toczący się w dniach 24 listopada - 16 grudnia 1947 r. Co warto podkreślić, nie ma żadnych wątpliwości co do faktycznego udziału tłumaczy w tych ważnych dla świata procesach ${ }^{8}$.

Jednocześnie nie wolno zapominać o udziale tłumaczy w dwóch odbywających się wiele lat po II wojnie światowej procesach zbrodniarzy nazistowskich w Jerozolimie: Adolfa Eichmanna sądzonego w latach 1961-1962 oraz Ivana Demianiuka, którego procesy odbywały się w latach 1987-1988, a następnie - w Monachium - w latach 2009-2011. Mimo doniosłości wszystkich wspomnianych wydarzeń oraz kluczowego znaczenia udziału w nich tłumaczy „tłumaczenie sądowe jest kopciuszkiem przekładu ustnego: pozbawioną czaru dziewczyną [...]" , a postrzeganie tłumaczenia sądowego jako gorszej odmiany przekładu ustnego wynika stąd, że tradycyjnie było to tłumaczenie wykonywane przez osoby

7 M. Tryuk, Przektad ustny konferencyjny, Wydawnictwo Naukowe PWN, Warszawa 2007, s. 101.

${ }^{8}$ Ibidem, s. 57-66.

9 J. Repa, Training and Certification of Court Interpreters in a Multicultural Society, „Meta” 1991, vol. 36, no. 4, s. 595. 
wielojęzyczne, które jednak nie posiadały przygotowania zawodowego. Ta cecha tłumaczenia sądowego zbliża go do kategorii tłumaczenia środowiskowego. Niemniej jednak, w odniesieniu do sytuacji tłumacza sądowego w Polsce, właśnie kryterium profesjonalizmu, a także zalecenie przestrzegania kodeksu etyki zawodowej tłumaczą różnicę między obydwoma rodzajami przekładu oraz stanowią o oryginalności i odrębności tłumaczenia sądowego.

Istotną datą w historii zawodu tłumacza sądowego jest rok 1953. Wówczas na paryskiej Sorbonie, podczas I Kongresu Światowego, z inicjatywy Pierre'a-François Caillé, została utworzona Międzynarodowa Federacja Tłumaczy (Fédération Internationale des Traducteurs) z siedzibą w Paryżu, a następnie w Genewie powstało Międzynarodowe Stowarzyszenie Tłumaczy Konferencyjnych AIIC (Association Internationale des Interprètes de Conférence). Te dwie organizacje były pierwszymi wśród wielu im podobnych, powstających na całym świecie i działających na rzecz podwyższenia rangi zawodu tłumacza. Innym prestiżowym towarzystwem zrzeszającym tłumaczy jest powstałe w 1997 r. Europejskie Stowarzyszenie Tłumaczy Sądowych EULITA (European Legal Interpreters and Translators Association). W Polsce w $1981 \mathrm{r}$. powstało Stowarzyszenie Tłumaczy Polskich, a następnie, założone 26 maja 1990 r., Polskie Towarzystwo Tłumaczy Ekonomicznych, Prawniczych i Sądowych „TEPIS”, (od 2002 r. funkcjonujące jako Polskie Towarzystwo Tłumaczy Przysięgłych i Specjalistycznych). Wszystkie wymienione organizacje są zwieńczeniem długoletnich starań tłumaczy na całym świecie o uznanie wykonywanego przez nich zajęcia jako pełnoprawnego zawodu, a także uwrażliwienie społeczeństwa na to, jak ogromną rolę tłumaczenie pełniło, pełni i niewątpliwie pełnić będzie w rozwoju cywilizacji, kontaktach międzyludzkich, ale także w życiu codziennym każdego człowieka.

W ostatnim ćwierćwieczu światem wstrząsnęły dwa wielkie konflikty, jakimi były wojny domowe, podczas których dopuszczono się masowego ludobójstwa. Mowa oczywiście o wojnie w Rwandzie w 1994 r., w wyniku której - według różnych szacunków - życie straciło od 800000 do 1000000 osób oraz wojna w Bośni i Hercegowinie w latach 1992-1995, gdzie wskutek czystek etnicznych zamordowanych zostało od 97000 do 110000 osób (niektóre źródła podają nawet 200000 ). W celu osądzenia sprawców obu tych wydarzeń Rada Bezpieczeństwa Organizacji Narodów Zjednoczonych powołała do życia Międzynarodowy Trybunał Karny dla Rwandy oraz Międzynarodowy Trybunał Karny dla byłej Jugosławii (MTKJ), oba z siedzibą w Hadze. Szczególnie precyzyjnie zostały zrelacjonowane procesy toczące się przed tym ostatnim organem sądowniczym. W stan oskarżenia za zbrodnie wojenne przed MTKJ postawionych zostało 161 osób. Znaczna część z nich posługiwała się jako ojczystym językiem bośniackim, serbskim i chorwackim (153 osoby), pozostali macedońskim ( 2 osoby) i albańskim (6 osób). Do 2013 r. Trybunał, składający się z sędziów pochodzących z 21 państw, przesłuchał ponad 4500 świadków. Mimo że zgodnie 
z regulaminem postępowania i w przedmiocie dowodów przed MTKJ językami roboczymi są angielski i francuski, to w razie ich nieznajomości zarówno oskarżeni, jak i świadkowie mają prawo do wypowiadania się w językach ojczystych, a specjalna sekcja przekładowa ma obowiązek zapewnienia właściwych usług tłumaczeniowych. W chwili otwarcia pierwszego przewodu sądowego w $1995 \mathrm{r}$. w jej skład wchodziło zaledwie dziesięciu tłumaczy. Dekadę później, gdy większość śledztw uległo już zakończeniu, a przed Trybunałem w Hadze toczyło się 10 postępowań sądowych jednocześnie, zaangażowanych w nie było nawet 170 tłumaczy. Bez ich pomocy nie byłoby możliwe osądzenie zbrodniarzy wojennych - Radovana Karadžicia i Ratka Mladicia, ani uprzednie opracowanie setek tysięcy stron dokumentów i dowodów, które posłużyły w postępowaniach przeciwko nim i innym sprawcom ludobójstw na Bałkanach.

Międzynarodowy Trybunał Karny w Hadze, jako pierwszy w historii ludzkości sąd międzynarodowy powołany do rozpoznania spraw osób oskarżanych o popełnienie najcięższych zbrodni, które miały miejsce po 1 lipca 2002 r., działa w sposób stały i nieprzerwany do dzisiaj, orzekając w sprawach ludobójstwa, zbrodni przeciwko ludzkości, zbrodni wojennych i agresji. Wśród czynów nieobjętych jurysdykcją Trybunału znajduje się zbrodnia terroryzmu, choć można w drodze wykładni odnośnych przepisów Statutu uznać ją za szczególny rodzaj przypadku zbrodni przeciwko ludzkości. Trybunał zatrudnia 571 osób z 83 państw, z czego lwią część personelu stanowią tłumacze, tłumaczący z i na sześć oficjalnych (angielski, francuski, rosyjski, hiszpański, arabski i chiński) oraz roboczych języków ONZ. Ale to nie jedyny organ sądowy prawa międzynarodowego, w którym pracują tłumacze. Wymienić należy w tym miejscu choćby Europejski Trybunał Praw Człowieka przy Radzie Europy w Strasburgu (powołany w 1959 r.) oraz Europejski Trybunał Sprawiedliwości Unii Europejskiej z siedzibą w Luksemburgu, powstały na mocy traktatu o Europejskiej Wspólnocie Węgla i Stali w 1952 r. Obie te instytucje, a w szczególności Trybunał UE, który zatrudnia tłumaczy wszystkich 24 języków oficjalnych wspólnoty, orzeka w sprawach wytoczonych przez rządy bądź obywateli państw członkowskich przeciwko rodzimym władzom, władzom innych państw bądź organom Unii Europejskiej, jak Komisja Europejska czy Rada Europejska ${ }^{10}$. Dla zapewnienia prawidłowego toku prowadzonych postępowań stałe uczestnictwo tłumaczy na każdym etapie przewodu sądowego jest konieczne i gwarantowane przepisami prawa obywatelowi każdego z państw członkowskich ${ }^{11}$.

W konkluzji pragnę podkreślić, że blisko 75 lat, które upłynęły od czasu zakończenia II wojny światowej i powołania wielu międzynarodowych organizacji

10 A. Jopek-Bosiacka, Przekład prawny i sądowy, Wydawnictwo Naukowe PWN, Warszawa 2006, s. 215.

11 S. Bailey-Ravet, Interpreting at the European Court of Human Rights in Strasbourg, „Lingua Legis” 2014, no. 22, s. 38-40. 
bezpieczeństwa, ich agend i organów sądowniczych to okres krótki w skali historii ludzkości, jednak bardzo owocny dla traduktologii i branży tłumaczeniowej. W tym czasie udało się przede wszystkim uregulować prawnie status tłumacza przysięgłego (czy, w tym przypadku, sądowego) zarówno w prawie międzynarodowym, jak i w jurysdykcjach narodowych. Badania nad przekładem, nie tylko te naukowe - teoretyczne, ale również w wymiarze stosowanym, praktycznym, uległy bardzo dużemu zintensyfikowaniu. Standardem na większości kierunków neofilologicznych i lingwistycznych w Europie i na świecie jest dziś prowadzenie zajęć specjalistycznych z języka prawa, ekonomii, medycyny i nauk technicznych. Istnieją wręcz ośrodki akademickie specjalizujące się wyłącznie w kształceniu tłumaczy praktyków. Jednocześnie wzrasta świadomość społeczna w tematach wielokulturowości i wielojęzyczności. Dostępność materiałów dydaktycznych i leksykograficznych oraz stosownego oprogramowania do nauki języków obcych jest nieporównywalnie wyższa nie tylko w stosunku do stanu sprzed 75 lat, ale nawet sprzed 20 lat. Te wszystkie czynniki pozytywnie wpływają także na rozwój zawodu tłumacza przysięgłego i specjalistycznego. Z drugiej strony, lokalne rozwiązania ustawowe (w szczególności wykonawcze, dotyczące choćby sposobu wynagradzania tłumaczy współpracujących z organami wymiarów sprawiedliwości i warunków ich pracy), jak również dydaktyczne (w wymiarze edukacji prawnej) oraz dążenia do ujednolicania terminologii pozostawiają pole do nieustannych ulepszeń, jakże koniecznych w zawodzie cieszącym się nie tylko wysoką oceną profesjonalną, ale i zaufaniem społecznym, zawodzie wymagającym wysokich standardów etycznych.

\section{Bibliografia}

Bailey-Ravet S., Interpreting at the European Court of Human Rights in Strasbourg, „Lingua Legis” 2014, no. 22, s. 38-40.

Biernacka A., Tłumacz w rozprawie sadowej, Wydawnictwo Naukowe Instytutu Kulturologii i Lingwistyki Antropocentrycznej, Uniwersytet Warszawski, Warszawa 2014.

Colin J., Morris R., Interpreters and the Legal Process, Waterside Press, Winchester 1996. Jopek-Bosiacka A., Przekład prawny i sadowy, Wydawnictwo Naukowe PWN, Warszawa 2006.

Kierzkowska D., Tłumaczenia prawnicze, Wydawnictwo Translegis, Warszawa 2008.

Pieńkos J., Podstawy juryslingwistyki. Język w prawie - Prawo w języku, Muza SA, Warszawa 1999.

Repa J., Training and Certification of Court Interpreters in a Multicultural Society, „Meta” 1991, vol. 36, no. 4, s. 595-605.

Tryuk M., Poczatki ttumaczenia konferencyjnego w Polsce. Pierwszy etap profesjonalizacji ryn$k u$, [w:] 50 lat polskiej translatoryki, red. K. Hejwowski, A. Szczęsny, U. Topczewska, 
Instytut Lingwistyki Stosowanej, Uniwersytet Warszawski, Warszawa 2009, s. 57-66.

Tryuk M., Przekład ustny konferencyjny, Wydawnictwo Naukowe PWN, Warszawa 2007.

Tryuk M., Ttumaczenie sadowe. Od teorii do praktyki, [w: ] O tłumaczach, prawnikach, lekarzach i urzędnikach. Teoria i praktyka przekładu środowiskowego $w$ Polsce, red. M. Tryuk, BEL Studio, Warszawa 2010, s. 15-64.

Wróblewski B., Język prawny i prawniczy, Polska Akademia Umiejętności, Kraków 1948.

\section{Akty prawne}

EUR-Lex. Baza aktów prawnych Unii Europejskiej, http://eur-lex.europa.eu (ostatni dostęp: 13.12.2019).

Konwencja o ochronie praw człowieka i podstawowych wolności z $1950 \mathrm{r}$.

Ustawa z dnia 25 listopada 2004 r. o zawodzie tłumacza przysięgłego (Dz.U. z 2004 r. Nr 273, poz. 2702). 